\title{
3D Technologies as the Future of Spatial Planning: the Example of Krakow ${ }^{6}$
}

\begin{abstract}
The main goal of the paper is to make a general assessment of the application of 3D technologies in spatial planning. It was performed with the city of Krakow as the case study. The paper describes the outline of the spatial planning system in Poland and the planning conditions of Krakow. The data obtained from laser scanning for Krakow are also briefly characterized. The possibility of using these data for locating high-rise buildings in terms of the protection of Krakow's panorama and within two programs "IT system of the Country's Protection Against Extreme Hazards" (ISOK) and "Integrated spatial data monitoring system for air quality improvement in Krakow" (MONIT-AIR) were analyzed in the paper. The main result of the research is the assessment of what studies or measurements may be used to meet particular spatial planning needs or requirements.
\end{abstract}

Keywords: spatial planning, urban planning, 3D modelling, Krakow, Airborne Laser Scanning (ALS), Light Detection and Ranging (LiDAR)

Received: 12 January 2019; accepted: 2 July 2019

(C) 2020 Authors. This is an open access publication, which can be used, distributed and reproduced in any medium according to the Creative Commons CC-BY 4.0 License.

AGH University of Science and Technology, Faculty of Mining Surveying and Environmental Engineering, Department of Geomatics, Krakow, Poland, email: agnieszka.bieda@agh.edu.pl

ORCID ID: https://orcid.org/0000-0002-9725-5960

2 AGH University of Science and Technology, Faculty of Mining Surveying and Environmental Engineering, Department of Geomatics, Krakow, Poland, email: jaroslaw.bydlosz@agh.edu.pl

ORCID ID: https://orcid.org/0000-0002-0350-8112

3 AGH University of Science and Technology, Faculty of Mining Surveying and Environmental Engineering, Department of Geomatics, Krakow, Poland, email: piotr.parzych@agh.edu.pl ORCID ID: https://orcid.org/0000-0002-4182-1978

4 Institute of Geodesy, Cartography and GIS, Faculty of Mining, Process Control and Geotechnologies, Technical University of Košice, Košice, Slovakia, email: katarina.pukanska@tuke.sk ORCID ID: http://orcid.org/0000-0002-7332-7691

$5 \quad$ ESW Wycena Nieruchomości, Krakow, Poland, email: biuro@esw24.pl

6 This work was financed by research funds from the AGH University of Science and Technology No. 16.16.150.545 and Grant Project of Ministry of Education of the Slovak Republic KEGA No. 004TUKE-4/2019 "Scientific and educational centre for remote sensing with the focus on the application of e-learning approaches in education". 


\section{Introduction}

Spatial planning concerns how people shape and manage space [1]. It differs from urban planning and architectural design as its final effect are maps (local development plans) [2], the creation of which requires the consideration of social, economic and environmental issues.

Envisaging our future is a collective responsibility of communities, planners and decision-makers, therefore visualization techniques are increasingly becoming an important tool applied in spatial planning [3]. Planning analyses are more comprehensive if they can be done in three-dimensional space [4].

The paper [5] describes 29 different possibilities of using 3D modelling that include urban design. However, the spatial planning where areas with specific designation are arranged, instead of locating construction objects in space, is missing.

While the creation of 3D models of whole cities or their fragments is acceptable in urban design [6-19], the authors ask whether conducting analyses in three-dimensional space for the purpose of spatial planning is reasonable as well. According to the authors, conducting 3D analyses could facilitate the creation of planning studies in three-dimensional space. This view is consistent with the already published proposal to include spatial planning objects in the 3D cadastre [20].

As part of the research, an analysis of selected elements of the Polish spatial planning system was carried out. The study focused on the provisions related to the conditions taken into account when destined land for specific purposes and establishing the principles of its development and build-up. Attempts were made to link the 3D analyses carried out for the city of Krakow (Poland) which were possible to perform with them on the basis of data obtained from Airborne Laser Scanning (ALS).

\section{Polish Spatial Planning System}

As indicated in [21-28], planning procedures in European Union countries have significant similarities. Therefore, this paper focuses only on the Polish spatial planning system.

Spatial planning processes are hierarchical in Poland and are conducted within three levels of detail:

1) national,

2) regional,

3) local (municipal) $[29,30]$.

Appropriate planning documents are prepared at all levels. The characteristics of the most important ones are presented in Table 1. 
Table 1. Characteristics of planning documents prepared in Poland

\begin{tabular}{|c|c|c|}
\hline Level & Planning document & Description \\
\hline \multirow[t]{2}{*}{ Country } & $\begin{array}{l}\text { The concept of spatial } \\
\text { development of the country }\end{array}$ & $\begin{array}{l}\text { Approved by the Council of Ministers regulation. } \\
\text { It defines the conditions, objectives and directions } \\
\text { of country sustainable development and the actions } \\
\text { necessary to achieve it }\end{array}$ \\
\hline & $\begin{array}{l}\text { Programs aimed at the } \\
\text { realization of a public } \\
\text { purpose development of } \\
\text { national importance }\end{array}$ & $\begin{array}{l}\text { Prepared by ministers and central government } \\
\text { administration authorities, within the scope of their } \\
\text { material competence. They take into account the same } \\
\text { objectives and directions as the concept of spatial } \\
\text { development of the country. Adopted by the Regulation } \\
\text { of the Council of Ministers }\end{array}$ \\
\hline Region & $\begin{array}{l}\text { Spatial development plan of } \\
\text { the region }\end{array}$ & $\begin{array}{l}\text { Enacted by the regional council, taking into account the } \\
\text { arrangements of the spatial development concept of the } \\
\text { country }\end{array}$ \\
\hline \multirow[t]{3}{*}{ Municipality } & $\begin{array}{l}\text { Study of conditions and } \\
\text { directions of spatial } \\
\text { development }\end{array}$ & $\begin{array}{l}\text { Resolution of the commune council, which is created in } \\
\text { order to define the commune's spatial policy, including } \\
\text { local spatial development principles. It is prepared for } \\
\text { the area of the whole commune. It is not a document } \\
\text { of local law. Its provisions are binding when creating } \\
\text { a local spatial development plan }\end{array}$ \\
\hline & $\begin{array}{l}\text { Local spatial development } \\
\text { plan }\end{array}$ & $\begin{array}{l}\text { Resolution of the Commune Council drawn up in } \\
\text { order to determine the designation of land, including } \\
\text { the public purpose development, and to determine the } \\
\text { methods of its development and build-up. It does not } \\
\text { have to cover the whole commune. It is an act of local } \\
\text { law. Administrative decisions are issued on its basis }\end{array}$ \\
\hline & $\begin{array}{l}\text { Decision on built-up } \\
\text { conditions and spatial } \\
\text { development }\end{array}$ & $\begin{array}{l}\text { In the absence of a local development plan, a change } \\
\text { in land use consisting in the construction of a building } \\
\text { or the carrying out of other construction works, as } \\
\text { well as a change in the use of the building or its part } \\
\text { requires a decision on the terms and conditions of } \\
\text { development. Such a decision is made by the head of the } \\
\text { commune, mayor or president of the city at the request } \\
\text { of the interested party. A public purpose development } \\
\text { is located at the developer's request, basing on the } \\
\text { decision on its location. Depending on the importance } \\
\text { of the development, a public administration body at the } \\
\text { commune or region level may be involved }\end{array}$ \\
\hline
\end{tabular}

Source: own study based on [31]

The creation of any such document must be preceded by detailed analyses. According to the Act [31], spatial planning and development in Poland in particular takes into account:

- requirements of spatial arrangement, including urban planning and architecture;

- architectural and landscape assets; 
- environmental protection requirements, including water management and protection of agricultural and forest land;

- requirements for the protection of cultural heritage and monuments and contemporary cultural assets;

- requirements for the protection of health and safety of people and property, as well as the needs of the disabled;

- economic qualities of the space;

- the right of ownership;

- the needs of state defense and security;

- the need for public interest;

- needs for the development of technical infrastructure, in particular broadband networks;

- ensuring public participation in works on the study of conditions and directions of spatial development of the commune, the local spatial development plan and the regional spatial development plan, including through the use of electronic forms of communication;

- maintaining openness and transparency of planning procedures;

- the need to ensure adequate quantity and quality of water for the purposes of supplying the population.

\section{Spatial Planning in Krakow}

Krakow is located in southern Poland, in the central-western part of the Małopolskie Province, on the Vistula River (Fig. 1). The city is located in a valley, at the confluence of several geographical regions, in close proximity to the Tatra Mountains - the highest range in the Carpathian chain. It is the second largest city in Poland in terms of area $\left(327 \mathrm{~km}^{2}\right)$ and population $(769,498)$. The population density in Krakow is diversified and amounts to an average of 2,348 inhabitants per square kilometre [32].
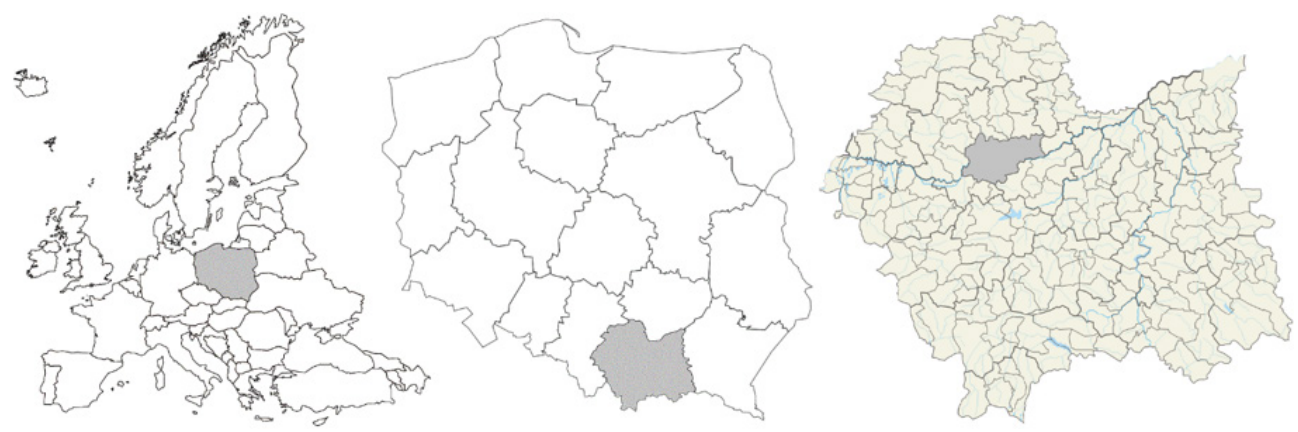

Fig. 1. Krakow localisation 
The extent of the city from south to north is $18 \mathrm{~km}$, and from west to east $31 \mathrm{~km}$. The highest point in the city is Józef Piłsudski's Mound, $383 \mathrm{~m}$ above sea level. The lowest point in Krakow is the estuary of the Kościelnicki Creek (187 m above sea level).

Due to the fact that Krakow was the city for the coronation of Polish kings and became their necropolis, and also that there are many cultural institutions of national importance and the oldest university in Poland (the Jagiellonian University, founded in 1364), the city attracts crowds of students, tourists and investors. As a result, and to improve the quality of life of city inhabitants, the Krakow authorities are constantly working on new planning documents. The aim is to contribute to the continuous sustainable development of the city.

Among the 16 capitals of Polish regions, at the end of 2017, Krakow was ranked 6th in terms of the percentage of the area covered by the current local spatial development plans (Fig. 2).

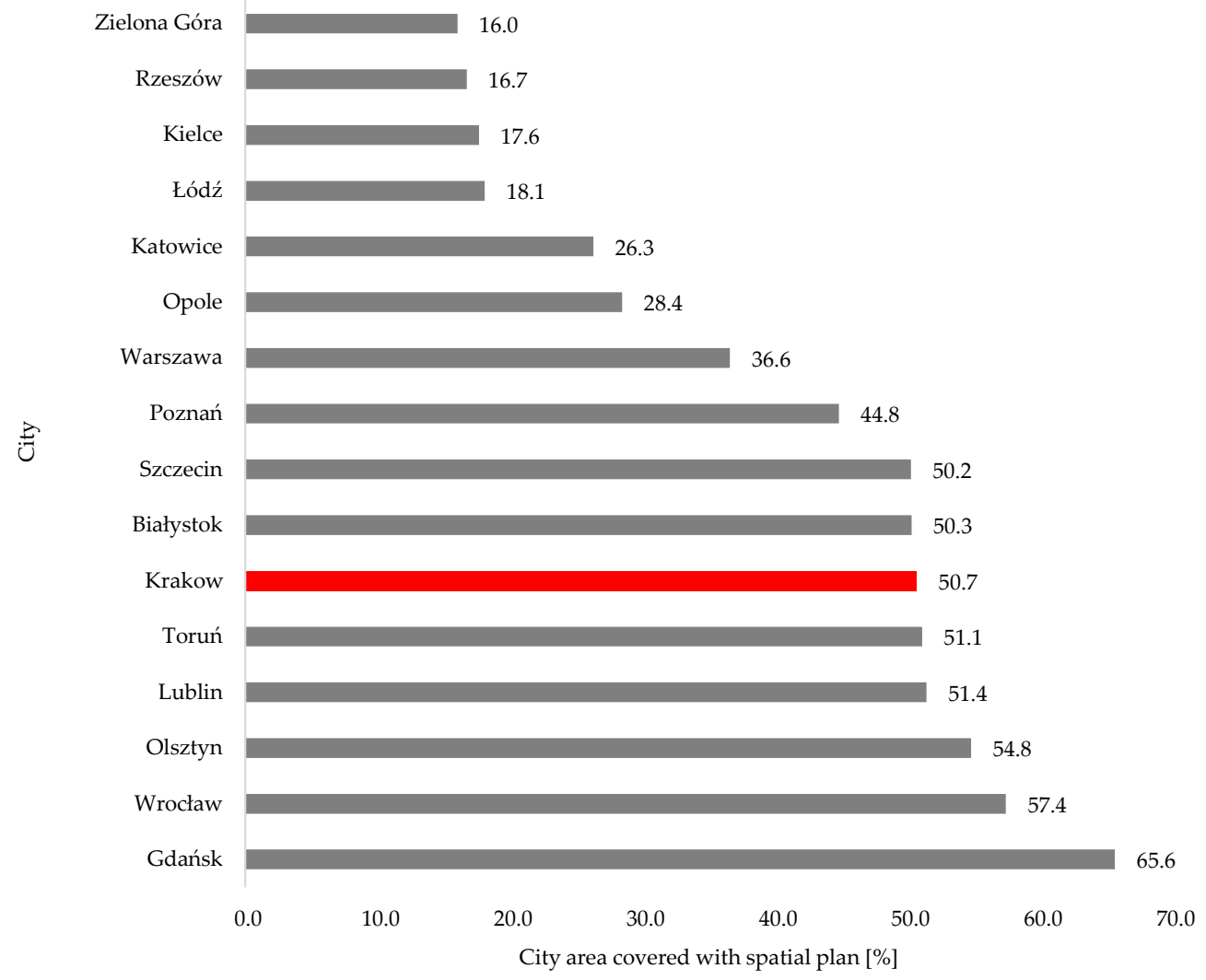

Fig. 2. Area of provincial capitals covered by local spatial development plans - as at 31.12.2017 Source: own study based on [33] 
What is important, the area covered by local spatial development plans is constantly increasing (Fig. 3). Nevertheless, many development works in Krakow are still being carried out on the basis of administrative decisions on built-up conditions and spatial development.
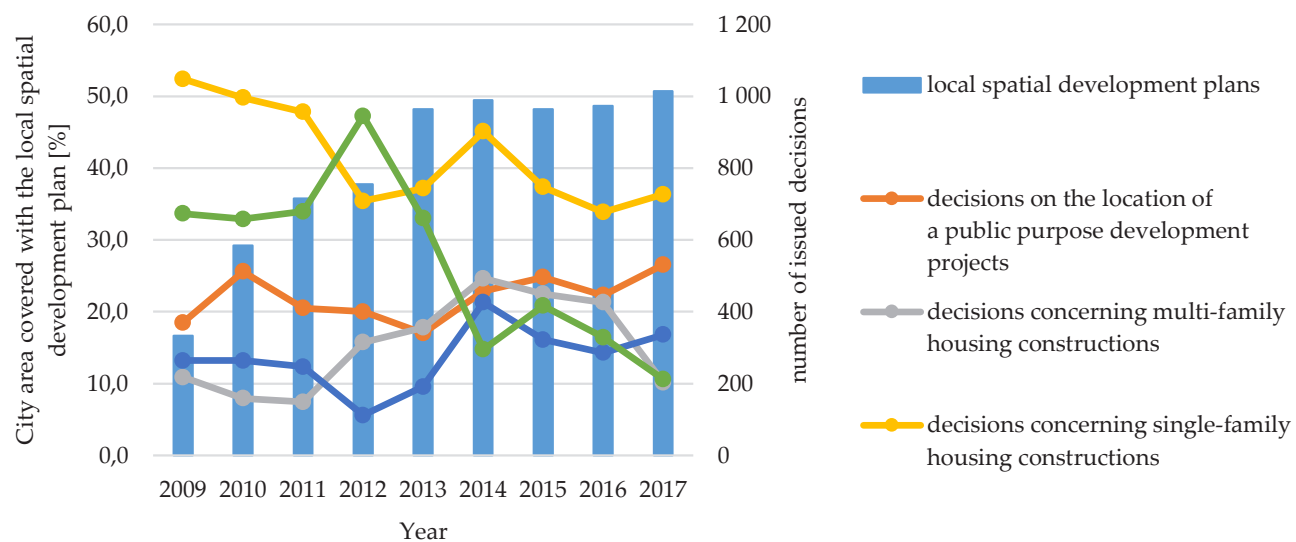

Fig. 3. Area of Krakow covered by local spatial development plans and number of issued decisions on built-up conditions and spatial development in the years 2009-2017 Source: own study based on [33]

As of 15 November 2018, 184 local spatial development plans in Krakow are in force, which cover slightly more than $60 \%$ of the city's area. The next 2 plans are awaiting their entry into force and 53 are in the process of preparation (Fig. 4).

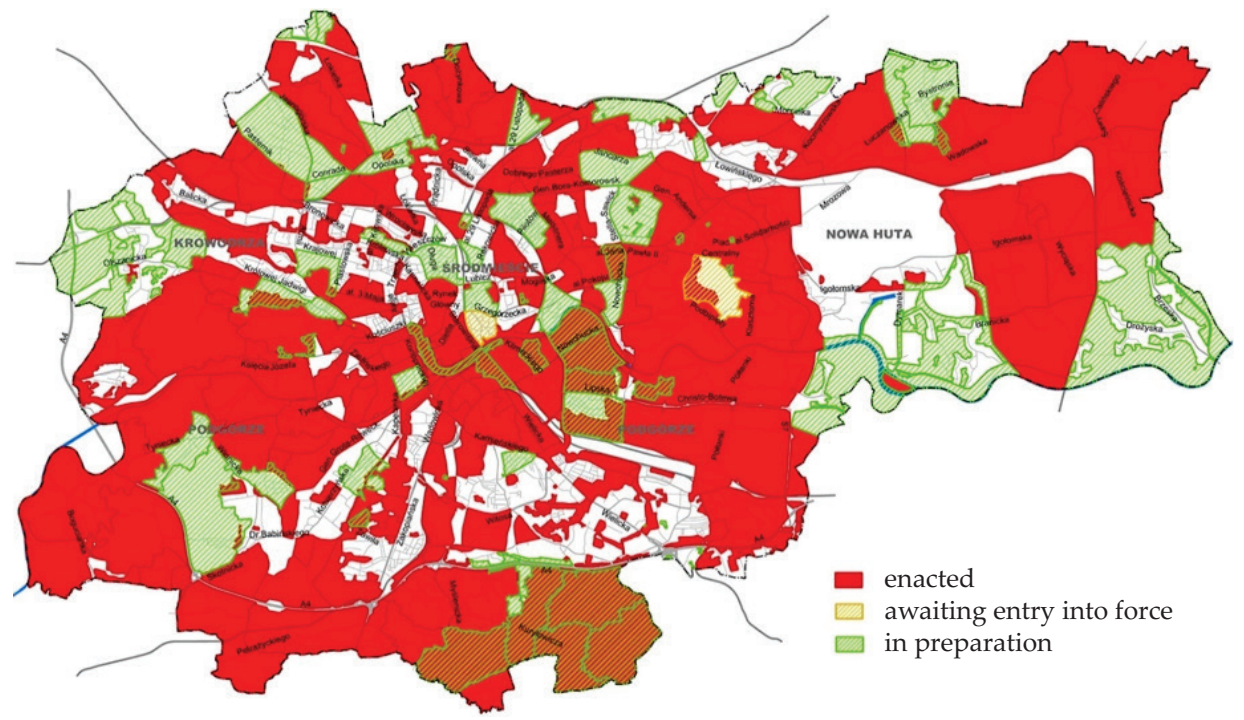

Fig. 4. Local spatial development plans in Krakow - as of 15.11.2018

Source: [34] 
These documents are intended not only to create a new development, but primarily to organize the already existing ones with the simultaneous activation of development processes. The introduction of clear regulations coordinating and ordering the existing development is aimed at avoiding the kind of chaos that could lower the historical value of Krakow space [35].

\section{Laser Scanning Data}

The analyses described above were performed on the basis of data obtained through airborne laser scanning, which took place twice (Tab. 2).

Table 2. Airborne laser scanning of Krakow

\begin{tabular}{||c|c|c|l||}
\hline Year & $\begin{array}{c}\text { Flight } \\
\text { altitude }[\mathrm{m}]\end{array}$ & $\begin{array}{c}\text { Point cloud density } \\
{\left[\text { point } / \mathrm{m}^{2}\right]}\end{array}$ & \multicolumn{1}{|c||}{ Measurement system } \\
\hline \hline 2006 & 350 & $\mathrm{~min} .12^{*}$ & FLI-MAP 400 (helicopter mounted) \\
\hline 2012 & 880 & 12 & $\begin{array}{l}\text { LMS-Q680i RIEGL laser scanner with GPS/INS: } \\
\text { AeroControl and Hasselblad50 aerial camera } \\
\text { (mounted on Cessna T206H aircraft) }\end{array}$ \\
\hline
\end{tabular}

* There are regions with a density of $16-20$ points $/ \mathrm{m}^{2}$ in the study area.

Source: own study based on [36, 37]

The aerial measurements that took place in 2006 were ordered by the Krakow City Authority [36]. On the other hand, the measurements from 2012 were taken as part of a nationwide project aimed at creating an IT system for the Country's Protection Against Extreme Hazards (Polish acronym ISOK) [38].

On the basis of the measured points, it is possible to make a digital terrain model with a very realistic appearance, where even very small details can be easily observed (Fig. 5).

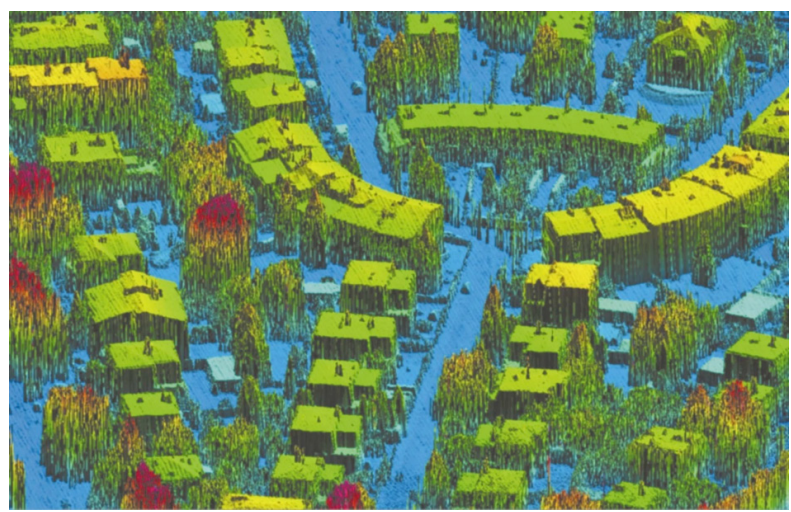

Fig. 5. A fragment of a numerical housing model of an urban complex represented by an irregular grid of triangles made on the basis of data from 2006 
On the basis of data obtained in 2006, the Spatial Planning Bureau of the City of Krakow performed an analysis in the year 2009 concerning the possibility of locating high-rise buildings in the aspect of city panorama protection [39].

The data obtained as a result of the aerial measurements from 2012 were used to prepare flood hazard maps and flood risk maps as part of the Information System for Protection against Exceptional Hazards (ISOK) [38], as well as to carry out analyses as part of the project "Integrated monitoring system of spatial data to improve air quality in Krakow" (MONIT-AIR), which started in 2014 [40].

\section{Discussion}

The result of the research on the source materials is a description of the analyses which were carried out in three-dimensional space, within the framework of the projects mentioned above. The authors believe that each of them could be used to a significant extent in the creation of planning documents at the local level.

\section{Possibility of Locating High-Rise Buildings \\ in Terms of the Protection of the Panorama of the City of Krakow}

The aim of the analysis was to examine the possibility of locating high-rise buildings, i.e. buildings with a height of more than $55 \mathrm{~m}$, in the area of Krakow. Its main assumption was to protect the panorama of the city (Fig. 6).

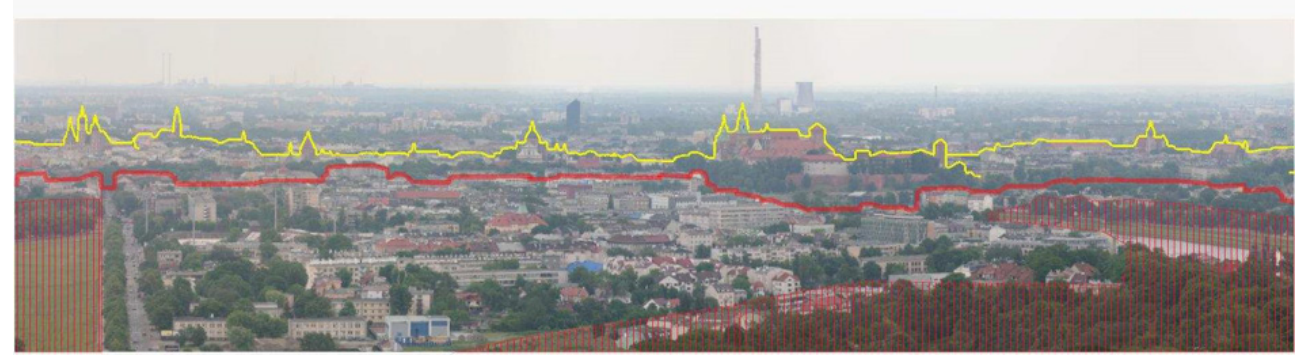

Fig. 6. Protected panorama of Krakow - view from Tadeusz Kościuszko Mound Source: [39]

The protected area was defined by designating dominant objects which form the most characteristic fragment of the historical silhouette of the city (Fig. $7 \mathrm{~b}$ ). The visibility analysis was carried out from four main viewpoints (Fig. 7a). The selection 
of specific viewpoints was determined by their cultural significance, frequency of attendance and the quality of exposure to the most valuable panoramas of Krakow (in particular to the Old Town, Wawel Royal Castle and Jewish Quarter Kazimierz, which were entered on the UNESCO World Heritage List).

a)

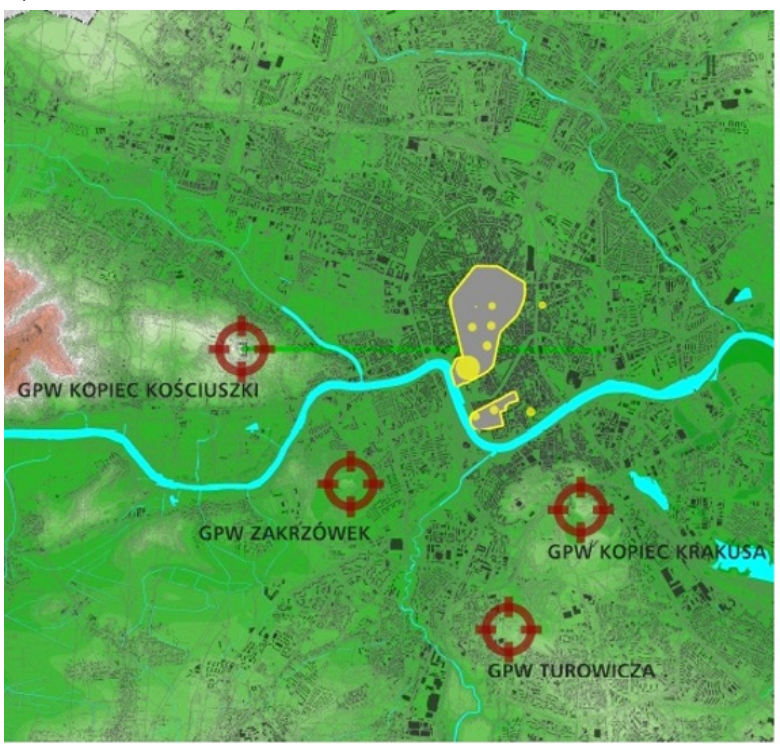

b)

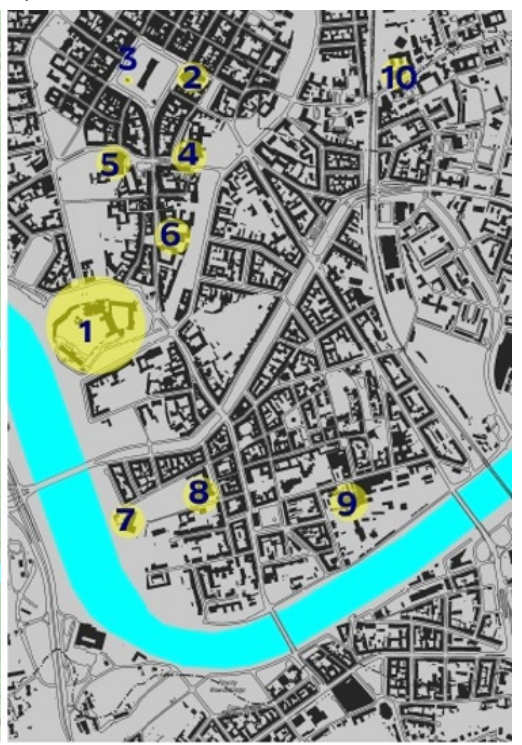

Fig. 7. Main viewpoints (a) and protected dominant features of Krakow silhouette (b):

1 - Wawel, 2 -St. Mary's Church, 3 - Town Hall Tower, 4 - Dominican Church,

5 - Franciscan Church, 6 - St. Peter's and Paul's Church, 7 - Church on the Rock, 8 - St. Catherine's Church, 9 - Corpus Christi Church, 10 - Jesuits Church

Source: [39]

The aim of the study required a method which, in an objective manner, within the boundaries of the whole city, would make it possible to define areas protected against high-rise build-up and those in which the locations of high buildings can be considered. The searches were carried out through subsequent analyses:

- the visibility fields from the main viewpoints (Fig. 8a),

- relative heights in the shadow zone of the protected silhouette (Fig. 8b),

- visibility of the foreground and background of the protected silhouette (Fig. 8c).

The last stage of the works was carried out in two-dimensional space. On the basis of the map of visibility of the foreground and the protected background, which was made using 3D analyses, after taking into account additional cultural and natural conditions, the areas where high objects can be created were determined (Fig. 8d). In order for this to happen, these areas should be designated for high-rise development in the relevant planning documents. 
a)

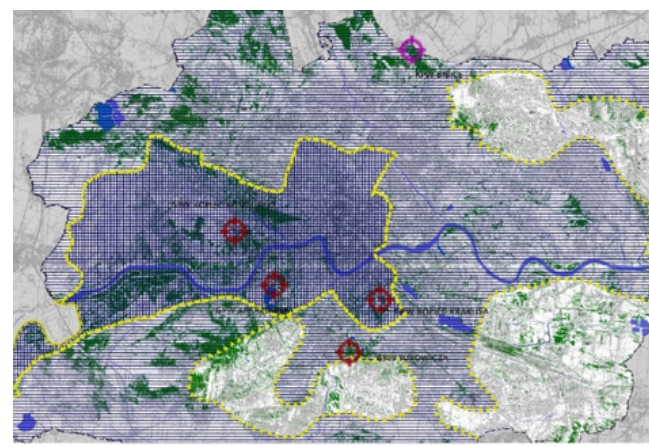

c)

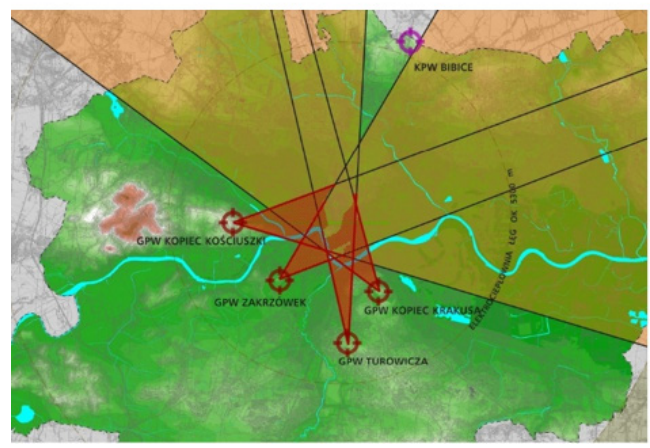

b)

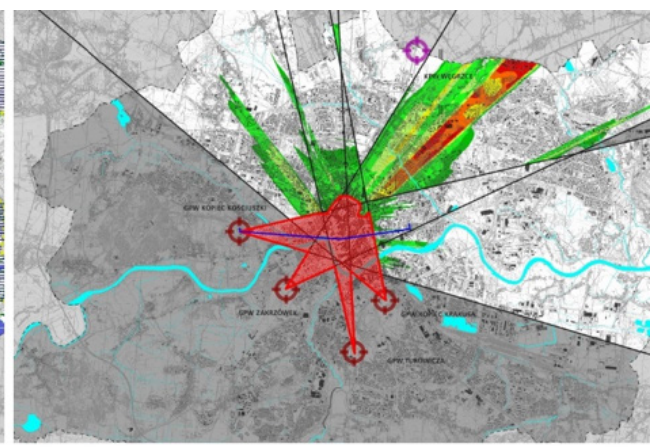

d)

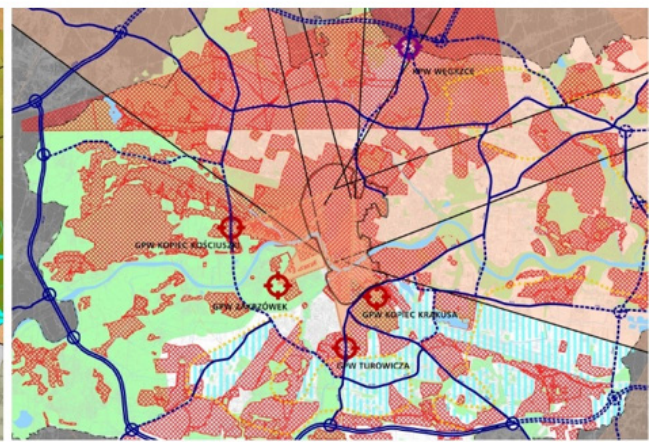

Fig. 8. Fragments of maps created to protect the Krakow silhouette: visibility of the area from the main viewpoints (a); areas visible from the main viewpoints where high objects will remain in the shadow of the protected panorama of the city (b); areas of visibility from the main viewpoints on the protected panorama of the city (c); areas where high objects can be created - marked with a light blue hatching (d)

Source: [39]

\section{IT system of the Country's Protection against Extreme Harazds (ISOK)}

As part of the research program, the Institute of Meteorology and Water Management of the Polish Research Institute, basing on a digital terrain model, created flood hazard maps and flood risk maps.

Flood hazard maps show areas with a certain probability of flooding, such as:

- areas where the probability of flooding is low - once per 500 years $(Q 0.2 \%)$,

- areas where the probability of flooding is medium - once per 100 years $(Q 1 \%)$,

- areas where the probability of flooding is high - once per 10 years $(Q 10 \%)$,

- areas exposed to flooding in the event of damage or destruction of a dike (Fig. 9). 


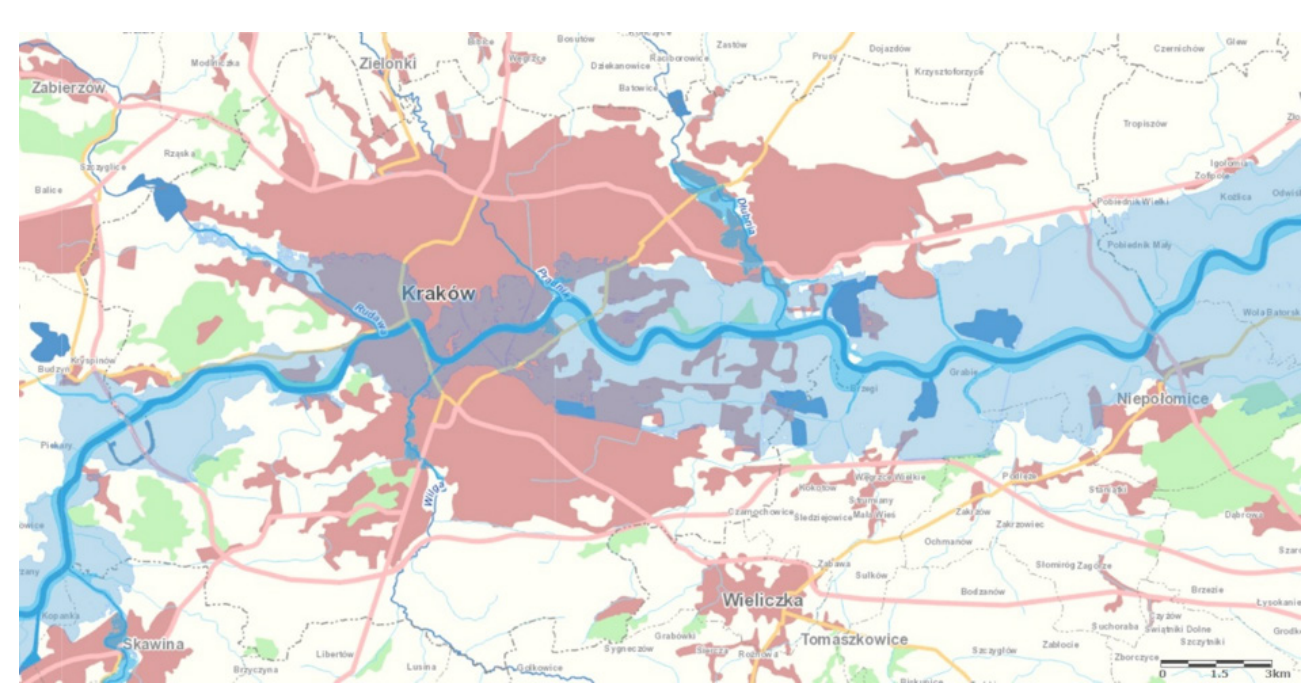

Fig. 9. The area of Krakow exposed to flooding in case of complete destruction of the dike

Source: [41]

Flood risk maps complement flood hazard maps. They no longer require $3 \mathrm{D}$ technology, which was necessary during the delimitation of floodplains.

These maps identify the values of potential flood losses and shall show the objects exposed to flooding with a certain probability of occurrence. They allow the assessment of flood risks to human health and life, the environment, cultural heritage and economic activity.

For this purpose, additional elements have been added to the areas presented in the flood risk maps:

- the estimated population living in the hazardous area;

- residential buildings and facilities of particular social importance (i.e. hospitals, schools, kindergartens, hotels, shopping centers and others) for which the floodwater depth is at least 2 meters;

- historic areas and objects;

- protected areas such as water intakes, water intake protection zones, bathing areas, nature protection areas;

- potential water pollution outbreaks in case of floods, such as industrial plants, sewage treatment plants, sewage pumping stations, landfills, cemeteries;

- the value of potential losses for individual land-use classes, such as residential areas, industrial areas, traffic areas, forests, recreational areas, agricultural land, water.

Examples of flood hazard maps and flood risk maps for the Krakow area, where the probability of flooding is once every 500 years, are presented in Figure 10. 
a)

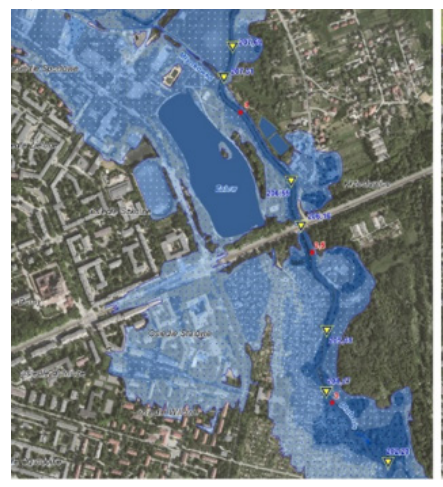

b)

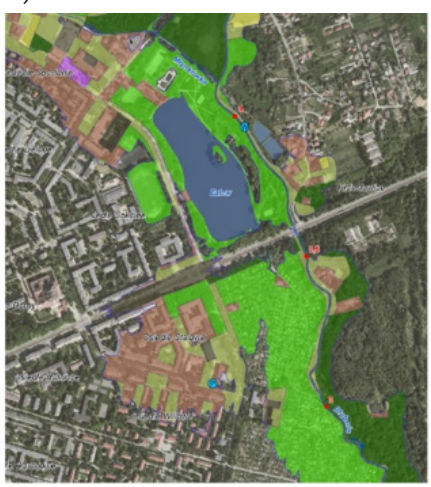

c)

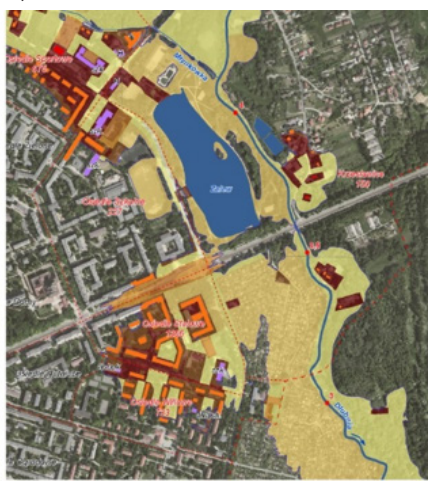

Fig. 10. Fragments of maps for the area where floods are likely to occur every 500 years: flood hazard map (a), flood risk map including negative consequences for the environment, cultural heritage and economic activity (b) and for the population including losses (c)

Source: [41]

As a result of the analyses carried out, areas were identified which, as a result of planning works, should be excluded from development, or where such development should be limited due to the danger to people and their property.

\section{Integrated Spatial Data Monitoring System \\ for Air Quality Improvement in Krakow (MONIT-AIR)}

The MONIT-AIR project consists of 8 separate but interdependent and complementary activities. The first one concerns the assessment of ventilation conditions in Krakow with the use of an advanced modelling system [40]. The most important results of this activity include: results of wind field modelling, as well as a map of greenery and ventilation conditions in Krakow (Fig. 11a) and a map of land cover and area roughness (Fig. 11b).

Maps based on 3D analysis contain information about the average wind speed of $10 \mathrm{~m}$ above ground level, conditions for locating gardens and photovoltaic cells on roofs, and aerodynamic roughness of the terrain. The obtained results may be helpful in determining the areas excluded from development in order to create air corridors for city ventilation or to identify areas beneficial for locating wind or solar power installations.

\section{Evaluation of the Possibility of Using the Existing 3D Analyses for Kraków in Spatial Planning}

Table 3 lists the statutorily required conditions of spatial planning [31], which according to the authors, may be taken into account in the new planning documents on the basis of the existing 3D analyses for Krakow. The table includes only those conditions for which at least one described study can be used. 
a)

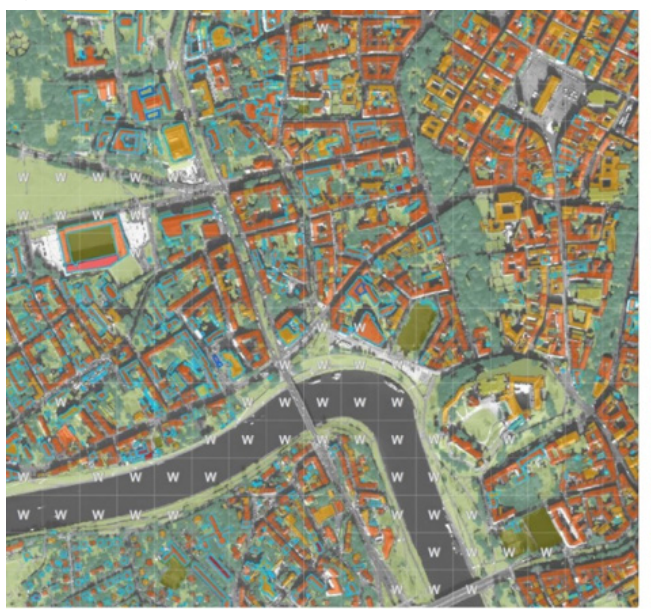

b)

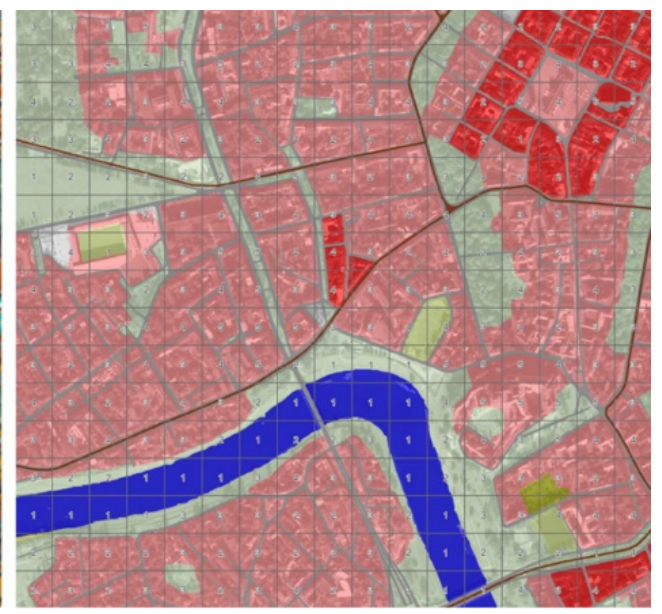

Fig. 11. Fragments of maps made in the MONIT-AIR project: a map of greenery and ventilation conditions in Krakow (a) and a map of land cover and area roughness (b) Source: [40]

Table 3. 3D analyses possible for application in spatial planning

\begin{tabular}{|l|c|c|c||}
\hline \multicolumn{1}{|c|}{ Condition } & Panorama protection & ISOK & MONIT-AIR \\
\hline Architectural and landscape values & + & & \\
\hline Environmental protection requirements & + & + & + \\
\hline Requirements for the cultural heritage protection & + & + & \\
\hline $\begin{array}{l}\text { Requirements for the health protection and persons } \\
\text { and property safety }\end{array}$ & + & + & + \\
\hline Economic qualities of space & + & & + \\
\hline National defence and security needs & & + & + \\
\hline Public interest needs & & + & + \\
\hline
\end{tabular}

The analysis concerning the possibility of locating high-rise buildings in Krakow is of course closely connected with the protection of cultural heritage and architectural and landscape assets. Its main objective was to protect the characteristic silhouette of the historical part of the city against covering or introducing any unfavorable dominant feature into it (or in its background). It made it possible to identify areas in which high buildings cannot be allowed. Importantly, defining an area as intended for high-rise development may have a significant impact on its value [42]. 
Analyses within the framework of the program creating the National IT system of the Country's Protection Against Extreme Hazards (ISOK) have led to the identification of floodplains, which should be excluded from the possibility of development in order to protect life and health and the safety of people and property. Such provisions have a direct impact on the value of properties which are exposed to flooding [43]. Indirectly, these analyses also indicate conditions related to environmental (mainly protection of water intakes) and cultural heritage protection. On the basis of this analysis, the public interest needs resulting from the necessity to repair or expand facilities related to flood protection are also met.

Analyses made during the implementation of the project concerning the integrated spatial data monitoring system for improving air quality in Krakow (MONIT-AIR) take into account, first of all, the requirements of environmental protection. However, it is also possible to identify the best locations for renewable energy installations, based on wind or sun for example. Of course, their use is connected with the state's energy security [44]. It also has an impact on the economic assets of the space it concerns.

\section{Conclusions}

Although it is easier to imagine the use of 3D technology in urban planning and architectural design, it is clear that not all analyses prior to assigning land for specific purposes and establishing the principles of land use and development must be carried out in three-dimensional space (Tab. 3). However, it cannot be overlooked that 3D modelling makes it much easier to carry out studies and that 3D visualization can be useful to ensure public participation in the creation of planning documents. Also important is that the conditions of spatial planning with the use of 3D technology can be taken into account much more precisely. Nevertheless, such practices are still rarely used, and it is difficult to find references to them in the literature.

As early as 2009, the Spatial Planning Bureau of the City of Krakow made 3D analyses which were used to determine the location of areas for high-rise development. The areas for which restrictions on development should be introduced in order to protect the characteristic panorama of the city were also determined, there. These analyses can be considered as the first studies dedicated to spatial planning conducted for Krakow in three-dimensional space.

As it has been noted when analyzing the results of work under the projects related to the creation of the IT system of the Country's Protection Against Extreme Hazards (ISOK) and the Integrated Spatial Data Monitoring System for the Improvement of Air Quality in Krakow (MONIT-AIR), spatial planning may also use studies which will identify areas that should be excluded from development due to the fact that they are at risk of flooding and because they are included in the system of air 
corridors for ventilation of the city. Similar analyses can be used to identify areas at risk of flooding during the location of hydroelectric power plants and flood protection dams, as well as to identify areas suitable for the location of wind farms.

In addition, three-dimensional analyses carried out for Krakow allowed to determine the buildings whose roofs can be used for the installation of photovoltaic installations on them. Similar maps made for non-urbanized areas, in turn, may allow sunlight to be included in the location of areas intended for agricultural production.

\section{References}

[1] Van Assche K., Beunen R., Duineveld M., de Jong H: Co-evolutions of planning and design: Risks and benefits of design perspectives in planning systems. Planning Theory, vol. 12(2), 2013, pp. 177-198.

[2] Lagopoulos A.P.: Clarifying Theoretical and Applied Land-Use Planning Concepts. Urban Science, vol. 2(1), 2018, p. 17.

[3] Pettit C.J., Cartwright W., Berry M.: Geographical visualization: A participatory planning support tool for imagining landscape futures. Applied GIS, vol. 2(3), 2006, pp. 22.1-22.16.

[4] Batty M., Chapman D., Evans S., Haklay M., Kueppers S., Shiode N., Smith A., Torrens P.M.: Visualizing the City: Communicating Urban Design to Planners and Decision-Makers. Centre for Advanced Spatial Analysis, London 2000.

[5] Biljecki F., Stoter J., Ledoux H., Zlatanova S., Çöltekin A.: Applications of 3D City Models: State of the Art Review. ISPRS International Journal of Geo-Information, vol. 4, 2015, pp. 2842-2889.

[6] Ranzinger M., Gleixner G.: GIS datasets for 3D urban planning. Environment and Urban Systems, vol. 21(2), 1997, pp. 159-173.

[7] Pullar D.V., Tidey M.E.: Coupling 3D visualisation to qualitative assessment of built environment designs. Landscape and Urban Planning, vol. 55(1), 2001, pp. 29-40.

[8] Appleton K., Lovett A.: GIS-based visualisation of rural landscapes: Defining "sufficient" realism for environmental decision-making. Landscape and Urban Planning, vol. 65(3), 2003, pp. 117-131.

[9] Métral, C., Falquet G., Vonlanthen M.: An ontology-based model for urban planning communication. [in:] Teller J., Lee J.R., Roussey C. (eds.), Ontologies for Urban Development, Studies in Computational Intelligence, 69, Springer-Verlag Berlin Heidelberg, 2007, pp. 61-72.

[10] Kibria M.S., Zlatanova S., Itard L., Dorst M.: GeoVEs as tools to communicate in urban projects: Requirements for functionality and visualization. [in:] Lee J., Zlatanova S. (eds.), 3D Geo-Information Sciences, Lecture Notes in Geoinformation and Cartography, Springer-Verlag Berlin Heidelberg, 2009, pp. 379-395. 
[11] Benner J., Geiger A., Häfele K.H.: Concept for building licensing based on standardized 3D geo information. International Archives of the Photogrammetry, Remote Sensing and Spatial Information Sciences, vol. XXXVIII-4/W15, 2010, pp. 9-12.

[12] Isikdag U., Zlatanova S.: Interactive modelling of buildings in Google Earth: A 3D tool for Urban Planning. [in:] Neutens T., de Maeyer Ph. (eds.), Developments in 3D Geo-Information Sciences, Lecture Notes in Geoinformation and Cartography, Springer-Verlag Berlin Heidelberg, 2010, pp. 52-70.

[13] Moser J., Albrecht F., Kosar B.: Beyond visualization - 3D GIS analyses for virtual city models. International Archives of the Photogrammetry, Remote Sensing and Spatial Information Sciences, vol. XXXVIII-4/W15, 2010, pp. 143-146.

[14] Guney C., Akdag Girginkaya S., Cagdas G., Yavuz S.: Tailoring a geomodel for analyzing an urban skyline. Landscape and Urban Planning, vol. 105(1-2), 2012, pp. 160-173.

[15] Lewis J.L., Casello J.M., Groulx M.: Effective environmental visualization for urban planning and design: interdisciplinary reflections on a rapidly evolving technology. Journal of Urban Technology, vol. 19(3), 2012, pp. 85-106.

[16] Czyńska K., Rubinowicz P.: Application of 3D virtual city models in urban analyses of tall buildings - Today practice and future challenges. Architecture et Artibus, vol. 19, 2014, pp. 9-13.

[17] Lu S., Wang F.: Computer aided design system based on 3D GIS for park design. [in:] Hsiang-Chuan Liu, Wen-Pei Sung, Wenli Yao (eds.), Computer, Intelligent Computing and Education Technology, CRC Press, London 2014, pp. 413-416.

[18] Kaňuk J., Gallay M., Hofierka J.: Generating time series of virtual 3-D city models using a retrospective approach. Landscape and Urban Planning, vol. 139, 2015, pp. 40-53.

[19] Leszek K.: Environmental and urban spatial analysis based on a 3D city model. [in:] Computational Science and Its Applications - ICCSA 2015, Theoretical Computer Science and General Issues, 9155, Springer International Publishing, New York 2015, pp. 633-645.

[20] Bydłosz J., Bieda A., Parzych P.: The Implementation of Spatial Planning Objects in a 3D Cadastral Model. ISPRS International Journal of Geo-Information, vol. 7(4), art. no. 153, pp. 1-14.

[21] Kwartnik-Pruc A., Przewięźlikowska A.: Porównanie funkcjonowania planowania przestrzennego w Polsce iw Niemczech. Geomatics and Environmental Engineering, vol. 1(3), 2007, pp. 149-160.

[22] Cieślak I.: Analiza systemu planowania przestrzennego we Francji w nawiazaniu do systemu polskiego. Acta Scientiarum Polonorum, Administratio Locorum, vol. 9(2), 2010, pp. 5-16.

[23] Golej J.: Porovnanie systémov územného plánovania v Taliansku a na Slovensku. Nehnutelnosti a Bývanie, no. 1, 2012, pp. 27-37. 
[24] Topczewska T.: Integrated planning of development and revitalisation of cities in selected countries of the European union and in Poland. Człowiek i Środowisko, t. 36(3), 2012, pp. 21-40.

[25] Krajewska M., Źróbek S., Kovač M.Š.: The role of spatial planning in the investment process in Poland and Slovenia. Real Estate Management and Valuation, vol. 22(2), 2014, pp. 52-66.

[26] Tölle A.: Zintegrowane formy planowania $i$ zarządzania rozwojem lokalnym a instrumentarium planistyczne - system polski na tle systemu niemieckiego. Studia Regionalne i Lokalne, nr 3(57), 2014, pp. 60-76.

[27] Pawlikowska E., Popek P., Bieda A., Moteva M., Stoeva A.: Analysis of the Legal Methods of Agricultural Land Protection in Central Europe on the Example of Poland and Bulgaria. Real Estate Management and Valuation, vol. 25(2), 2017, pp. 58-71.

[28] Bieda A., Pukanská K., Sala B.: Spatial planning in localities with special historic values on examples of Poland and Slovakia. Geomatics and Environmental Engineering, vol. 12(1), 2018, pp. 5-27.

[29] Koreleski K.: The system of spatial planning and land management in Poland. Geomatics and Environmental Engineering, vol. 3(2), 2009, pp. 27-42.

[30] Balawejder M., Matkowska K., Colak H.E.: The impact of surveying works on the Development of Smart City. [in:] Ćwiąkała P., Kwartnik-Pruc A., Puniach E. (eds.), "GIS ODYSSEY 2018”: geographic information systems conference and exhibition: $25^{\text {th }}$ anniversary conference: $10^{\text {th }}$ to $14^{\text {th }}$ of September 2018, Perugia, Italy: conference proceedings, Croatian Information Technology Society - GIS Forum, Zagreb 2018, pp. 20-32.

[31] Ustawa z dnia 27 marca 2003 r. o planowaniu i zagospodarowaniu przestrzennym. Tekst jednolity: Dz. U. 2018 poz. 1945 z późn. zm. [The Act of March 27, 2003, on planning and spatial development. Consolidated text: Journal of Laws of 2018, item 1945 as amended].

[32] Kraków w liczbach 2017 [Krakow in numbers 2017], http://www.bip.krakow.pl/ plik.php?zid=215089\&wer=0\& new=t\&mode=shw [access: 15.11.2018].

[33] GUS - Bank Danych Lokalnych [Statistics Poland - Local Data Bank], https://bdl. stat.gov.pl/BDL/start [access: 15.11.2018].

[34] Planowanie Przestrzenne - BIP MK - Urzad Miasta Krakowa [Planning Bureau of the City of Krakow], http://www.bip.krakow.pl/?id=412 [access: 15.11.2018].

[35] Bieda A., Parzych P.: Development of spatial politics of monumental towns based on Krakow example. [in:] SGEM 2013: GeoConference on Informatics, geoinformatics and remote sensing: $13^{\text {th }}$ international multidisciplinary scientific geoconference: 16-22, June, 2013, Albena, Bulgaria: conference proceedings. vol. 2, Geodesy and mine surveying; Photogrammetry and remote sensing, STEF92 Technology, Sofia 2013, pp. 143-150.

[36] Jędrychowski I.: Numeryczny model zespołów urbanistycznych w Krakowie. Roczniki Geomatyki - Annals of Geomatics, vol. 5(8), 2007, pp. 199-203. 
[37] Zięba K., Wężyk P. Wykorzystanie danych lotniczego skanowania laserowego (ALS) oraz analiz widoczności GIS do oceny przemian krajobrazu warownego Twierdzy Kraków. Roczniki Geomatyki - Annals of Geomatics, vol. 5(75), 2017, pp. 627-638.

[38] Wężyk P. (ed.): Podręcznik dla uczestników szkoleń z wykorzystania produktów LiDAR. Główny Urząd Geodezji i Kartografii, Warszawa 2015.

[39] Możliwości lokalizacji obiektów wysokościowych w aspekcie ochrony panoramy miasta Krakowa - analiza [Possibility of locating high-rise buildings in terms of protection city of Krakow panorama], http://www.bip.krakow.pl/?dok_id=28466 [access: 15.11.2018].

[40] Atlas pokrycia terenu i przewietrzania Krakowa [Land Cover and Ventilation Atlas of Krakow], http://progea4d.pl/atlas-pokrycia-terenu-i-przewietrzania-krakowa [access: 15.11.2018].

[41] Hydroportal publikujacy mapy zagrożenia powodziowego i mapy ryzyka powodziowego w formacie PDF, http://mapy.isok.gov.pl/imap/ [access: 15.11.2018].

[42] Adamczyk T., Bieda A.: Intended Use of Real Estate as a Time Changeable Attribute for Determining Compensation for Nationalized and Expropriated Lands. Real Estate Management and Valuation, vol. 22(4), 2014, pp. 35-50.

[43] Bieda A., Jasińska E.: Analysis of land exposed to the destructive activities of surface water flowing. [in:] FIG Commission 3: joint FIG/UN ECE workshop: workshop on Spatial information and FIG task force on Property and housing, and 2012 UNECE WPLA workshop on Informal development, property and housing: Athens, Greece, 10-14 December 2012, Greece, 2012.

[44] Bieda A., Bieda A.: Renewable energy in the system of spatial planning in Poland. [in:] Adamczyk T., Dębińska E. (eds.), "GIS ODYSSEY 2017": Geographic Information Systems Conference and Exhibition: $4^{\text {th }}$ to $8^{\text {th }}$ of September 2017, TrentoVattaro, Italy: conference proceedings, Croatian Information Technology Society - GIS Forum, Zagreb 2017, pp. 28-42.

\section{Technologie 3D przyszłością planowania przestrzennego: przykład Krakowa}

Streszczenie: Głównym celem artykułu jest ogólna ocena zastosowania technologii 3D w planowaniu przestrzennym. Została ona przeprowadzona na przykładzie miasta Krakowa. W artykule opisano zarys systemu planowania przestrzennego w Polsce oraz uwarunkowania planistyczne Krakowa. Krótko scharakteryzowano również dane uzyskane ze skaningu laserowego dla Krakowa. W pracy przeanalizowano możliwość wykorzystania tych danych do lokalizacji budynków wysokich w zakresie ochrony panoramy Krakowa oraz w ramach dwóch programów - „Informatyczny System Osłony Kraju przed nadzwyczajnymi zagrożeniami” (ISOK) i „Zintegrowany system monitorowania danych 
przestrzennych dla poprawy jakości powietrza w Krakowie" (MONIT-AIR). W wyniku przeprowadzonych analiz określono, jakie badania lub pomiary mogą być wykorzystane do zaspokojenia konkretnych potrzeb lub wymagań planowania przestrzennego.

\section{Słowa}

kluczowe: planowanie przestrzenne, planowanie urbanistyczne, modelowanie 3D, Kraków, lotniczy skaning laserowy (ALS), skaning laserowy 3D (LiDAR) 